\title{
Laccase from Lentinus polychrous Increases the Efficiency of Cellulose Hydrolysis of Rice Straw to Glucose
}

\section{RAKRUDEE SARNTHIMA and SARANYU KHAMMUANG*}

Protein and Enzyme Technology Research Unit, and Center of Excellence for Innovation in Chemistry, Department of Chemistry, Faculty of Science, Mahasarakham University, Maha Sarakham 44150 Thailand.

${ }^{*}$ Corresponding author E-mail: saranyukha@gmail.com

http://dx.doi.org/10.13005/ojc/3404033

(Received: June 28, 2018; Accepted: July 24, 2018)

\begin{abstract}
This study investigated the pretreatment of rice straw by crude laccase from Lentinus polychrous for preparation of lignocellulosic materials prior to be hydrolysed with cellulase for obtaining reducing sugar. Production of laccase involved cultivation of $L$. polychrous on solid media containing rice bran and rice husk supplemented with copper sulfate Pretreatment the rice straw was performed by incubating laccase $\left(2,5,10 \mathrm{U}\right.$ ) with $10 \mathrm{~g}$ of rice straw in buffer at 40 and $50^{\circ} \mathrm{C}$ for 24 hours. Then the rice straw was analyzed by fourier transform infrared spectroscopy (FT-IR). Laccase-pretreated rice straws were further hydrolyzed by commercial cellulase from Trichoderma reesei at activity of $0,10,20,30$ Filter Paper Unit (FPU) for 24 hours. Then reducing sugar was extracted and determined by the dinitrosalicylic acid (DNS) method. It was found that the rice straw pretreated with crude laccase gave a higher level of reducing sugar than that of crude laccase pretreatment. Rice straw hydrolyzed by $2 \mathrm{U}$ of laccase at 40 and $50^{\circ} \mathrm{C}$ yielded the highest reducing sugar at every cellulase activity used (10,20 and $30 \mathrm{FPU})$. The results showed that crude laccase could be applied to increase the efficiency of lignocellulose hydrolysis by cellulase.
\end{abstract}

Keywords: Lignocellulose, Laccase, Cellulase, Pretreatment, Biomass.

\section{INTRODUCTION}

Lignocellulosic biomass is a promising source for production of alternative fuels such as ethanol which can help to reduce the dependence on fossil fuels. In addition, it can be transformed to a wide ranges of different renewable products such as feed additives, chemicals and materials'. These processes are likely to become increasingly important in the near future as alternatives to the current petroleum-based industry. Thailand is one of the world's top rice growers and exporters. There is a surplus of rice straw, but it is used for very little apart from as cattle feed and rice straw is left behind in the rice fields throughout the country. Natural rice straw degradation takes a long time and it does not fit the schedules of farmers especially in the irrigated areas, where there are several rice crops

This is an Open Access article licensed under a Creative Commons Attribution-Non Commercial-Share Alike 4.0 International License (https://creativecommons.org/licenses/by-nc-sa/4.0/), which permits unrestricted Non Commercial use, distribution and reproduction in any medium, provided the original work is properly cited. 
each year. Therefore, many farmers choose the burn rice stubble on their fields which causes air pollution and loss of useful material. Effective use of this cellulosic material in our country will require much research. One of the most interesting uses is saccharification for the alcohol fermentation process. The rice straw, based on the dry weight composed of $36.8 \%$ cellulose, $25.8 \%$ hemicellulose, $15.8 \%$ lignin, $9.3 \%$ ash, $8 \%$ protein, and $6 \%$ extractives $^{2}$.

Biochemical conversion of lignocellulose to such products comprises three major steps; pretreatment, enzymatic hydrolysis and fermentation. Pretreatment is the step where lignin and hemicellulose are modified or removed and including altering the cellulose structure ${ }^{3}$. The enzymatic hydrolysis or saccharification step hydrolyses polysaccharides into fermentable sugars by the combined action of different enzyme activities. Finally, microorganisms convert sugars into alcohols, organic acids or other chemicals through fermentation processes ${ }^{4}$. At the pretreatment stage, several physical or chemical processes have been used. The drastic pretreatment conditions can not only result in biomass degradation but can generate different enzyme inhibitors such as phenolic compounds which decrease the efficiency of subsequent saccharification and fermentation steps ${ }^{5,6}$. Utilization of laccase has been reported to help hydrolysis of lignin therefore increasing sacharification yields ${ }^{5,6}$. Laccase from L. polychrous has been studied by our group and in varieties of applications ${ }^{7,8}$. However, the enzyme has not yet been studied for pretreatment of lignocellulosic materials. Therefore, this study evaluated laccase from L. polychrous as a tool for rice straw lignocellulose pretreatment and provides a first report of a saccharification model process using laccase from L. polychrous in pretreatment of ligninocellulosic material for cellulase saccharification.

\section{MATERIALS AND METHODS}

\section{Laccase preparation}

L. polychrous Lév. was cultured on GYP liquid medium (10 g/L glucose, $5 \mathrm{~g} / \mathrm{L}$ yeast extract, $5 \mathrm{~g} / \mathrm{L}$ peptone, and $1 \mathrm{~g} / \mathrm{L} \mathrm{MgSO}_{4} \cdot 7 \mathrm{H}_{2} \mathrm{O}$ ) at room temperature $\left(\sim 28 \pm 3^{\circ} \mathrm{C}\right)$ and $120 \mathrm{rpm}$ shaking. Various concentrations of copper sulfate $(0,0.2$, $0.5,1.0$ and $2.0 \mathrm{mM}$ ) were added into the medium at the 2 nd day after fungus was inoculated. Laccase activity was followed for 15 days.
Solid substrates of rice bran and rice husk were used as substrate for solid-state culture of the fungus $L$. polychrous, as previously described ${ }^{8}$ but with the presence of $\mathrm{Cu}^{2+}$ as a laccase inducer. Crude enzyme from L. polychrous was prepared by water extraction from the fungus cultured substrate at the ratio of $1: 4(\mathrm{w} / \mathrm{v})$. After centrifugation at $6,000 \mathrm{xg}$ for $15 \mathrm{~min}$. the supernatant (crude enzyme extract) was assayed for laccase activity and protein.

\section{Enzyme activity assay}

The crude enzyme was assayed for laccase activity based on the oxidation of 2,2'-azinobis (3-ethylbenzothiazoline-6-sulfonate) diammonium salt (ABTS; Sigma, USA), according to the previously described method ${ }^{8}$. Oxidation product of ABTS was monitored by a UV-Vis spectrophotometer at $420 \mathrm{~nm}\left(\varepsilon=3.6 \times 104 \mathrm{~L} \mathrm{~mol}^{-1} \mathrm{~cm}^{-1}\right)$. One unit of laccase activity is the amount of enzyme that catalyzes the oxidation of its substrate into corresponding product $1 \mu \mathrm{mol} / \mathrm{min}$. under the assay conditions.

Cellulase activity assay was performed by the filter paper assay (FPA) using Whatman No. 1. filter paper as the substrate ${ }^{9}$.

\section{Protein determination}

Soluble proteins in the crude enzyme extract were measured by the method of Bradford (1976)10 using the Bio-Rad Protein Assay Reagent (Bio-Rad, USA) with bovine serum albumin (BSA) as a standard protein.

\section{Analysis of laccase pretreated rice straws by Fourier Transform-Infrared Spectroscopy}

Rice straws were washed with water to remove dust or contaminants, cut to a size of $0.5^{-1} \mathrm{~cm}$ and dried at $70^{\circ} \mathrm{C}$. Removal of lignin in rice straw was performed by adding $80 \mathrm{~mL}$ of $10 \mathrm{mM}$ sodium acetate $\mathrm{pH} 4.5$ into a $250 \mathrm{ml}$-Erlenmeyer flask containing $10 \mathrm{~g}$ rice straw followed by sterilization at $121^{\circ} \mathrm{C}$ for $30 \mathrm{~min}$. and left to cool down to room temperature. The crude laccase was added to sterilized rice straw at the ratio of enzyme per rice straw 2, 5, 10 $\mathrm{U}$ per $10 \mathrm{~g}$ of rice straw (or $0.025,0.062$ and 0.125 $\mathrm{U} / \mathrm{ml}$, respectively) and incubated at 40 and $50^{\circ} \mathrm{C}$ for 24 hours. The reactions were decanted and the pretreated rice straws were washed with $3 X 100 \mathrm{ml}$ deionized (DI) water and oven dried at $70^{\circ} \mathrm{C}$ until they reached a constant weight. The laccase pretreated 
rice straws were analyzed by Fourier TransformInfrared Spectroscopy.

\section{Analysis of reducing sugar release from laccase} pretreated rice straw hydrolyzed with cellulase

The laccase pretreated rice straws were further hydrolyzed by commercial cellulase (cellulase from Trichoderma reesei ATCC 26921, Sigma) at the ratio of cellulase per $1 \mathrm{~g}$ rice straws of $10,20,30$ FPU in $20 \mathrm{ml}$ of $50 \mathrm{mM} \mathrm{Na}$-citrate buffer $\mathrm{pH} 4.8$ and incubate at $45^{\circ} \mathrm{C}$ for 24 hours. After that cellulase hydrolyzed rice straws were extracted with distilled water (30 $\mathrm{ml})$ and were analysis for reducing sugar by dinitrosalicylic method (DNS method) ${ }^{11}$.

\section{Statistical analysis}

Results were presented as mean \pm standard deviation and one-way analysis of variance (ANOVA) (SPSS Statistics version 18) in order to determine significant statistical differences among samples. The differences in means were determined at the confidence level $\mathrm{P}<0.05$.

\section{RESULTS AND DISCUSSION}

Laccase production by L. polychrous in liquid and solid medium

In liquid medium, highest laccase activity

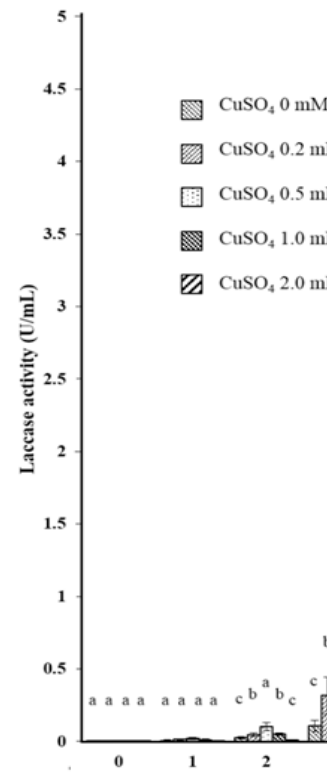

was observed on days 11-13 after inoculation. Using copper sulfate as inducer, it was found that highest laccase activity (about $3.6 \mathrm{U} / \mathrm{mL}$ ) was obtained at day-13 using $1 \mathrm{mM} \mathrm{CuSO}_{4}$ (Fig. 1). Laccase activity clearly dropped when using $2 \mathrm{mM} \mathrm{CuSO}_{4}$ indicating that toxicity of copper ions to the fungus as discussed in a previous report $^{12}$. Laccase production by liquid culture in 250 $\mathrm{mL}$-Erlenmeyer flasks did not has enough laccase activity to study rice straw pretreatment. Therefore, laccase production by solid-state fermentation was chosen instead. Zymograms of laccase isozyme patterns produced by liquid culture at day-5, day-10 and day-15 were analyzed (Fig. 2). Laccase isozyme pattern at each concentration of $\mathrm{CuSO}_{4}$ inducer $(0,0.2,0.5,1$ and $2 \mathrm{mM})$ gave the same patterns at different times of growth. It was obvious that laccase induction with higher concentration of $\mathrm{CuSO}_{4}(2 \mathrm{mM}$ ) showed different isozyme pattern compared to lower $\mathrm{CuSO}_{4}$ induction.

The crude enzyme in solid medium was extracted by distilled water ( $1 \mathrm{~g}$ solid medium: $4 \mathrm{~mL}$ distilled water). It was found that the crude enzyme had a protein concentration of $0.265 \mathrm{mg} / \mathrm{mL}$ and laccase activity of $3.96 \mathrm{U} / \mathrm{mL}$, therefore, the specific activity was $14.94 \mathrm{U} / \mathrm{mg}$ protein. In solid state fermentation we used $1 \mathrm{mM} \mathrm{CuSO}_{4}$ for induction and we cultured for three weeks.

Fig. 1. Laccase production at various times and induced by various concentrations of $\mathrm{CuSO}_{4}$. Different letters showed above the columns of each time demonstrate significant difference $(p<0.05)$ 


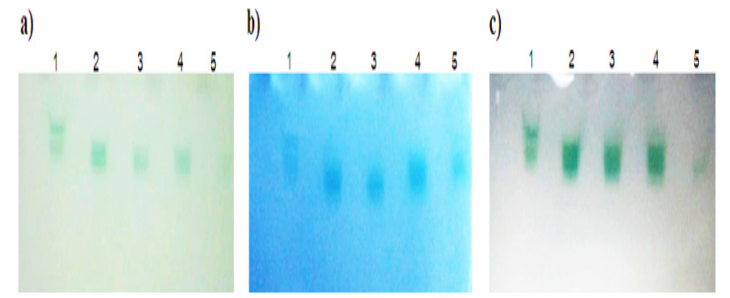

Fig. 2. Zymogram of laccase activity at various concentrations of $\mathrm{CuSO}_{4}$ induction at various culture times; day-5 (a), day-10 (b) and day-15 (c). lane 1; 0 mM, lane 2; $0.2 \mathrm{mM}$, lane 3; $0.5 \mathrm{mM}$, lane 4; $1 \mathrm{mM}$, lane 5; $2 \mathrm{mM}$, respectively

Rice straw pretreated by crude laccase and analysis by Fourier Transform-Infrared (FT-IR) Spectroscopy

Rice straws were pretreated with the crude laccase at two different temperatures $\left(40^{\circ} \mathrm{C}\right.$ and $50^{\circ} \mathrm{C}$ ). After that they were analyzed by FT-IR. The FT-IR spectra shown here are the spectra of rice straw pretreated with laccase at $40^{\circ} \mathrm{C}$ compared to the untreated one (Fig. 3.). The untreated rice straw showed a broad peak at $3414 \mathrm{~cm}^{-1}$ which is associated with the stretching of $\mathrm{H}$-bonded $\mathrm{OH}$ groups ${ }^{13}$, and showed increased absorbance with narrowing peak in case of crude laccase pretreatment which indicates the change in hydrogen bonding energy occurred ${ }^{14}$. The peak intensity at $2918 \mathrm{~cm}^{-1}$ from $-\mathrm{CH}_{2}$ groups slightly reduced in the crude laccase pretreated rice straw which was due to degradation of the lignocellulosic content of rice straw ${ }^{15}$.

The band at $1735 \mathrm{~cm}^{-1}$ characteristic of $\mathrm{C}=\mathrm{O}$ stretching, which has been ascribed to hemicelluloses is reduced in pretreated wheat straw16. In our work, the band observed slightly reduced at around $1742 \mathrm{~cm}^{-1}$ also confirmed the presence of the carbonyl group of hemicellulose ${ }^{17}$. Absorption at $1638 \mathrm{~cm}^{-1}$ could be attributed to the vibration of aromatic units in the lignin of rice straw. Lower band intensity at $1638 \mathrm{~cm}^{-1}$ in laccasepretreated sample was observed due to aromatic skeletal vibration ${ }^{18}$.

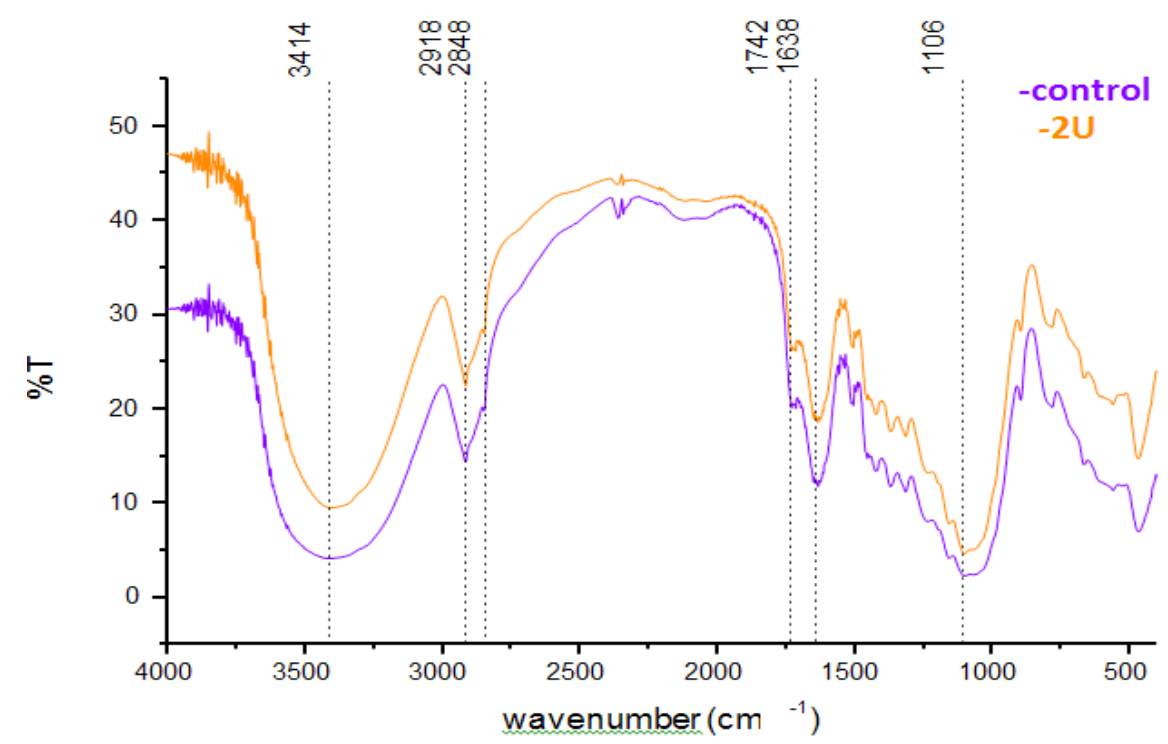

Fig. 3. The FT-IR spectra of the laccase pretreated (2 $\mathrm{U}$ laccase, $0.025 \mathrm{U} / \mathrm{ml}$ ) and untreated rice straw (control)

Slight decreases in the regions around $1330 \mathrm{~cm}^{-1}$ and $1265 \mathrm{~cm}^{-1}$ were observed in the laccase pretreated sample which referred to vibrations of the aromatic skeleton of syringyl alcohol and guaiacol alcohol, respectively ${ }^{19}$. The decrease in the transmission of these regions revealed the destruction of lignin structures in pretreated rice straw compared to the untreated. The adsorption at about $1160 \mathrm{~cm}^{-1}$ and $1106 \mathrm{~cm}^{-1}$ are from C-O-C bonds of $\beta(1 \rightarrow 4)$-glycosidic bond. These absorption bands indicated the presence of cellulose units in rice straw ${ }^{15}$. And after pretreatment in this study showed the absorption band at $1106 \mathrm{~cm}^{-1}$ indicating the remaining glycosidic bond of cellulose unit which support the low biomass loss before saccharification process.

Two temperatures $\left(40\right.$ and $\left.50^{\circ} \mathrm{C}\right)$ were chosen for rice straw pretreatment by crude laccase, which based on our previous studies, laccase from 
L. polychrous has been shown to work well between $40-50^{\circ} \mathrm{C}^{20}$. The FT-IR spectrum of crude laccase treated rice straw was generally similar to untreated rice straw. This result implied that crude laccase from L. polychrous under the chosen experimental conditions showed insufficient ability for degradation of rice straw. However, slightly differences could be observed between FT-IR spectrum derived from rice straw pretreated and untreated with laccase. Previous study showed a significant difference of FT-IR spectra between untreated and laccase treated saw dust ${ }^{18}$ although a laccase mediator system was used which made laccase more powerful activity for delignification.

\section{Analysis of reducing sugar derived from rice straw after pretreatment with crude laccase and hydrolysis with cellulase}

Rice straws pretreated with the crude laccase $\left(40\right.$ and $\left.50^{\circ} \mathrm{C}\right)$ were further hydrolyzed by different concentrations of commercial cellulase $(0,10,30$ and $30 \mathrm{FPU})$ per $1 \mathrm{~g}$ pretreated rice straw for 24 hours. Reducing sugar released were estimated by the DNS method. It was found that the amount of reducing sugar of the extracts of rice straws pretreated with laccase and then hydrolyzed with cellulase at all concentrations performed gave reducing sugar ranging from 9.9-17.3 mM. However, in rice straw pretreated with laccase at $40^{\circ} \mathrm{C}$ (Fig. 4a), there was no significant difference in the maximum reducing sugar using cellulase $20 \mathrm{FPU}$ or $30 \mathrm{FPU}$. It was obvious that at every concentration of cellulase used, the maximum amount of reducing sugar was obtained when $2 U$ of crude laccase applied. The highest glucose concentration obtained were about 15.7 and 17.3 mM at 20 FPU and 30 FPU of cellulase with no significant difference. Similar results have been obtained with the rice straw pretreated with laccase at $50^{\circ} \mathrm{C}$ (Fig. 4b). The maximum glucose concentration obtained were about 14.7 and $16.5 \mathrm{mM}$ at $20 \mathrm{FPU}$ and $30 \mathrm{FPU}$ of cellulase with significant difference. It is obvious that the highest glucose concentration obtained with laccase pretreatment at $40^{\circ} \mathrm{C}$ was a bit higher than that at $50^{\circ} \mathrm{C}$ at every cellulase activity used. Enzyme stability might be affected with high temperature. Therefore, between the two temperatures tested, $40^{\circ} \mathrm{C}$ should be chosen for pretreatment of rice straw with crude laccase from L. polychrous.
It was also clear that pretreatment with laccase higher than $2 \mathrm{U}$ (per $10 \mathrm{~g}$ rice straw) yielded glucose levels lower than with no laccase pretreatment. Since we used the crude laccase from rice solid-state culture of the rice husk and bran, it is possible that the enzyme solution may have contained phenolic compounds of lignin monomer derived from substrates. Moreover, lignin monomers and other phenolic compounds derived from the laccase catalyzed the rice straw might also have been present. The higher activity of crude laccase may yield higher levels of such inhibitor compounds. It is possible that cellulase enzyme was inhibited by these compounds ${ }^{21}$. High amounts of crude laccase used therefore could have contained higher amount of compounds with cellulase inhibitory ability. Laccase enzyme itself had been reported to inhibit cellulase and even when inactive could affect glucose releasing efficiency of cellulase hydrolysis ${ }^{22}$. Our study would suggest that using proper amount of crude laccase and more purified laccase, contain less inhibitor compounds before enzymatic hydrolysis process, should be in much more consideration. Laccase pretreatment of rice straw in this study could give maximum yields of reducing sugars (equivalent to glucose) of about $17.3 \mathrm{mM}$ which equals to $155.8 \mathrm{mg} / \mathrm{g}$-substrate (rice straw) and corresponds to $15.58 \%$. Simultaneous pretreatment and saccharification of biomass (SPS) process for rice straw and willow has been reported effectively using crude laccase from Tyromyces chioneus $(\mathrm{TCLac})^{23}$. In comparison with this latter study, our results yielded 2-times lower yield of reducing sugar. However, the results from this study are similar as pretreatment of corn stover with crude laccase from Coridus versicolor which gave a sugar yield $153 \pm 2.6 \mathrm{mg} / \mathrm{g}^{22}$

However, sugar yield might be improved when (a) rice straw is soaked (for several days) before pretreatment (b) milling and sieving rice straw to $\mathrm{mm}$ scale (c) using longer crude laccase pretreatment times (d) excessive washing after pretreatment to remove lignin, phenolic and compounds produced from laccase pretreatment that could be the inhibitors of subsequence hydrolysis enzyme in saccharification process ${ }^{22}$. 

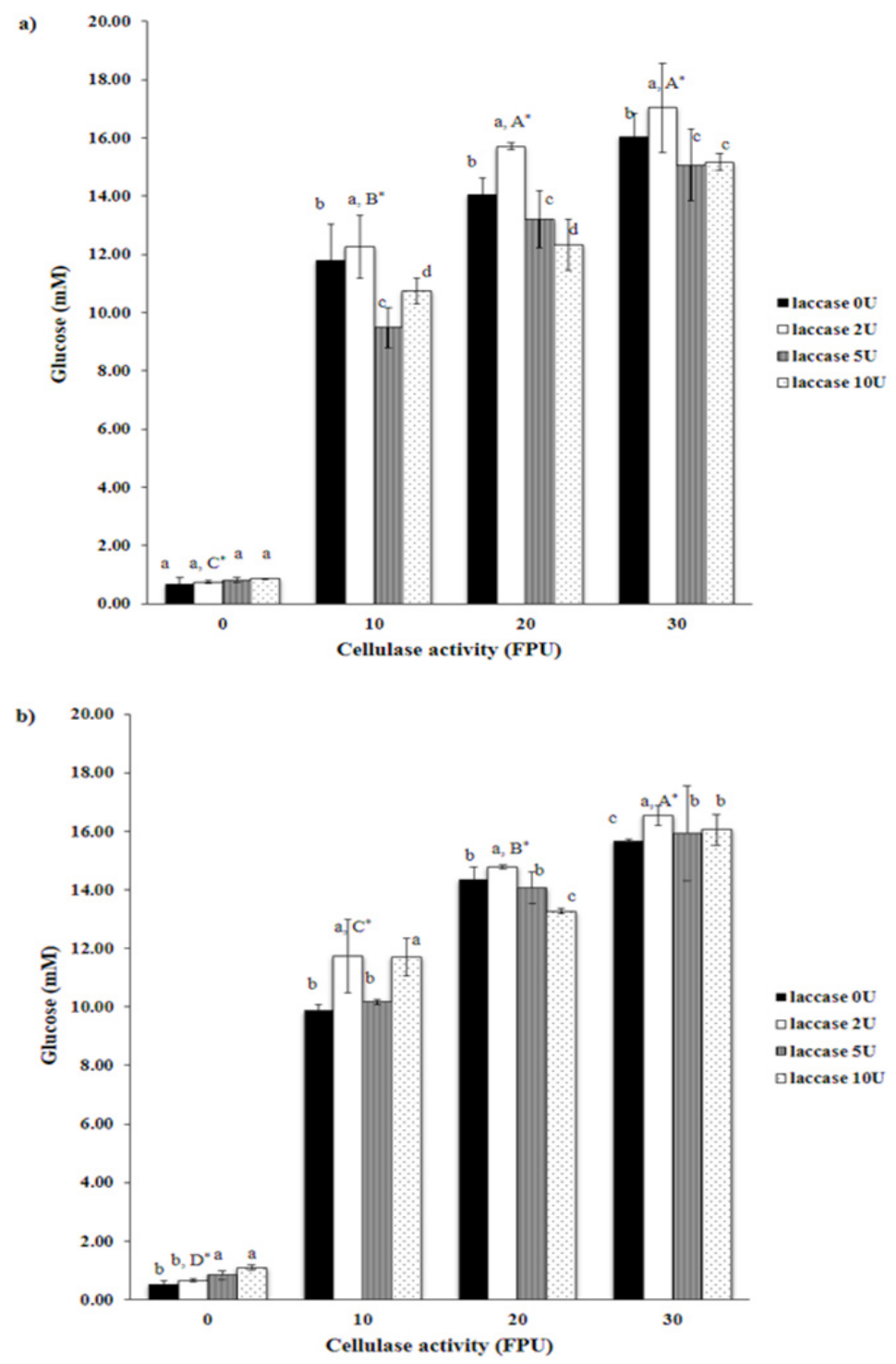

Fig. 4. Reducing sugar released from rice straw hydrolyzed with crude laccase at $40^{\circ} \mathrm{C}$ (a) and $50^{\circ} \mathrm{C} \mathrm{(b)} \mathrm{and} \mathrm{followed} \mathrm{by}$ hydrolysis with cellulase at different activities. Different letters showed above each columns demonstrate significant difference $(p<0.05)$

\section{CONCLUSION}

A crude laccase from $L$. polychrous might be an alternative choice for pretreatment of rice straw lignocellulosic material in the hydrolytic processing by cellulase. This treatment could help cellulase to hydrolyse cellulose in rice straw more efficiency as observed from higher amount of reducing sugar released in laccase pretreated rice straw than without pretreatment. The results implied the potential application of the crude laccase, in a low cost biorefinery production process to produce alternative fuels or fine chemicals from rice straw and other biomass.

\section{ACKNOWLEDGEMENT}

This research was supported by the Higher Education Research Promotion (HERP), grant no. 2558A10962021 (FY2015) under Khammuang, S. as a principal investigator. The authors also would like to thank Jariya Suraudorn and Arpakorn Donvichan for helping with experiments. 


\section{REFERENCES}

1. Cherubini, F.; Storman, A.H. Energy Fuels ., 2010, 24, 2657-2666.

2. Lee, K.-M.; Kalyani, D.; Tiwari, M.K.; Kim, T.-S.; Dhiman, S.S.; Lee, J.-K.; Kim, I.-W. Bioresour.Technol., 2012, 123, 636-645.

3. Narron, R.H.; Kim, H.; Chang, H.; Jameel, H.; Park, S. Curr. Opin. Biotech., 2016, 38, 39-46.

4. Fillat, Ú.; Ibarra, D.; Eugenio, M.E.; Moreno, A.D.; Tomás-Pejó, E.; Martín-Sampedro, R. Fermentation., 2017, 3, 17.

5. Palmqvist, E.; Hahn-Hägerdal, B. Bioresour Technol., 2000a, 74, 17-24.

6. Palmqvist, E.; Hahn-Hägerdal, B. Bioresour Technol., 2000b, 74, 25-33.

7. Khammuang, S; Sarnthima, R. Folia Microbiologica., 2013, 58, 1-7.

8. Sarnthima, R.; Khammuang, S.; Svasti, J. Biotechnol Bioprocess Eng., 2009, 14, 513-522.

9. Zhang, P.Y.H.; Himmel, M.E.; Mielenz, J.R. Biotechnol. Adv., 2006, 24, 452-481.

10. Bradford, M.M. Anal Biochem., 1976, 72, 248-254.

11. Miller, G.L. Anal. Chem. 1959, 31, 426-428

12. Khammuang, S.; Yuwa-amornpitak, T.; Svasti, J.; Sarnthima, R. Biocatal Agric Biotechnol ., 2013, 2, 357-362.
13. Wang, L.; Han, G.; Zhang, Y. Carbohydr. Polym., 2007, 69, 391-397.

14. Cao, Y.; Tan, H. J. Mol. Struct., 2004, 705, 189- 193.

15. Rungrodnimitchai, S. Sci World J., 2014, Article ID 634837.

16. Kristensen, J.B.; Thygesen, L.G.; Felby, C.; Jørgensen, H.; Elder, T. Biotechnol Biofuels., 2008, 1, 5.

17. Li, H.L.; Li, Z.; Peng, P.; She, D.; Xu, Q.; Zhang, X.M. J Appl Polym Sci., 2015, 132, 42790. DOI: 10.1002/APP.42790.

18. Bagewadi, Z.K.; Mulla, S.I.; Ninnekar, H.Z. Int J Recycl Org Waste Agricult., 2017, 6, 351.

19. Zeng, J.; Singh, D.; Chen, S. Bioresour Technol., 2011, 102, 3206-3214.

20. Suwannawong, P.; Khammuang, S.; Sarnthima, R. J Biochem Tech., 2010, 3, 182-186.

21. Kellock, M.; Rahikainen, J.; Marjamaa, K.; Kruus, K. Bioresour Technol., 2017, 232, 183-191.

22. Wang, F.-Q; Xie, H.; Chen, W.; Wang, E.-T.; Du, F.-G.; Song, A.-D. Bioresour Technol., 2013, 144, 572-578.

23. Dhiman, S.S.; Haw, J.-R.; Kalyani, D.; Kalia, V.C.; Kang, Y.C.; Lee, J.-K. Bioresour Technol., 2015, 179, 50-57. 